\title{
IMPROVEMENT OF COMPETENCE OF LABOUR PROTECTION SPECIALISTS
}

\author{
Dace Brizga, Vija Ozolina, Linards Sisenis, Anzelika Dorofejeva \\ Latvia University of Life Sciences and Technologies, Latvia \\ dacebrizga@inbox.lv, vrozolini@gmail.com, linards.sisenis@1lu.lv, zela5@inbox.lv
}

\begin{abstract}
Nowadays, work is becoming more dynamic; requiring great attention, maximizing the mental and physical abilities of the worker who suffers poor health as a consequence. It is essential for the employer to determine in a timely manner whether workplace risks cause adverse effects on employees' health and whether the labour protection specialist is fit for the job to be performed. A high quality master program promotes students' preparedness to meet economic sector requirements, and ensures long-term work and life environment sustainability. This is accompanied by mandatory health screenings intended to identify health problems in a timely manner. The tasks of the labour protection specialist are to find regulations to support the primacy of effective and high quality mandatory health screenings, to reduce the incidence of perfunctorily compliant attitudes among employees to health protection, and to promote long-term quality of life. The study was conducted using questionnaires (418 respondents) and expert interviews. The IBM SPSS 23 (Statistical Package for the Social Sciences) was used for analysis of the data generated by the employee survey. It has been found that the effectiveness of mandatory health screenings is intrinsically connected to their quality. The more competent, conscientious and honest is each participant in this activity - the employer, occupational physician and employee - the more effective is the mandatory health screening. The study identified the need to increase the competence of labour protection specialists by improving the master program to ensure the necessary raising of awareness in the context of mandatory health screening.
\end{abstract}

Keywords: effectiveness, employees, mandatory health screening, occupational diseases, quality.

\section{Introduction}

A high quality master program shall promote students' preparedness to meet economic sector requirements, and ensures long-term work and life environment sustainability. When a Senior Labour Protection Professional acquires the Master's Degree in Occupational Safety he or she also acquires professional competence, which, in accordance with the Vocational Education Law [1], means that this professional competence is the sum of knowledge, skills and responsibilities required for professional activity in a given work situation (Theoretical and practical preparedness, which provides an opportunity to perform work to a certain level of complexity and responsibility). The Professional Standard for a Senior Specialist in Labour Protection [2] states that a senior occupational safety specialist must have the ability to survey, monitor and control the work environment of the company, ensuring occupational safety and health at the workplace, and to arrange mandatory health examinations.

Statistics show that in 2018 , as in 2017 , the highest number of first-time occupational diseases was confirmed in manufacturing - 368; 334 in transport and storage, and 206 in health and social care. More than half $(53.5 \%)$ of first-time occupational health patients were confirmed in these sectors. In 2018 the most frequently diagnosed occupational diseases were of the nervous system (928) and musculoskeletal connective tissue (529), as well as injuries, poisoning and other consequences of external damage (188) [3]. Studies [4;5] show that compulsory health checks are still of poor quality and ineffective. This is exacerbated by a lack of occupational physicians and a lack of professional competence. As a result, mandatory health screenings (hereinafter referred to as MHS) are expensive and ineffective. Austrian researchers [5] have recommended better compulsory health insurance and family physician accountability. The family physician must have relevant competence corroborated by certificates.

In Latvia, the employer sends employees to the occupational health physician for health screening in accordance with the Cabinet Regulation No. 219 "Procedures for the Performance of Mandatory Health Examinations" [6], and secures a work environment risk assessment to be performed by a health and safety specialist.

As a result, a competent senior labour safety specialist is co-responsible for the health and safety of employees in the working environment. The employer assigns the employee to the compulsory health examination accompanied by two copies of mandatory health screening card prepared on the basis of an assessment of the work environment risks performed by a competent work protection 
specialist at the relevant workplace. The card consists of three parts, each with a name and the person responsible for filling in the information. The first and third parts of the card shall be completed by the consignor for the mandatory health screening. The second part of the card is to be evaluated by the occupational health physician. A study on diagnostic problems of occupational diseases in Latvia [7] found that occupational diseases are usually diagnosed in middle-aged people, when there are already signs of disability and it is difficult for the patient to find new occupation. Early detection of an occupational disease could often lead to a cure or improvement in the patient's health condition, making it possible to find another job for the patient. This study also shows that the average age of patients at the time of diagnosis is 51, and that the majority (71\%) live in cities, $65 \%$ are employed, and $72 \%$ are disabled. Occupational disease sufferers $(59 \%)$ did not discuss health problems with their employer, whereas in those who had, the occupational disease was recognised more quickly. The health problems were not reported during the MHS by $39.5 \%$ of occupational disease sufferers. Formal attitudes by attending physicians during the MHS were perceived by $40 \%$ of the participants in the study, and in this group the diagnosis of the occupational disease was delayed by 17 years, while in those patients to whom the physician listened carefully the delay was only seven years. Similar studies show [8] that there is a direct correlation between a positive working environment and the efficiency and sustainability of the company as a whole.

The tasks of the labour protection specialist are to find regulations to support the primacy of effective and high quality mandatory health screenings, to reduce the incidence of perfunctorily compliant attitudes among employees to health protection, and to promote long-term quality of life. Significant opportunities for changing the employers' and employees' attitude towards work safety can be achieved by appropriate improvements in education, both in educational institutions and in work places [9].

Latvia's problem is the vast number of occupational diseases. In order to ensure competent and adequate supervision and control in the field of labour protection, it is advisable to update the issues on the reduction of the occupational diseases in the educational programmes [10]. The principal challenge is how to include and stress the importance of occupational diseases and mandatory health checks in educational programmes $[11 ; 12]$.

\section{Materials and methods}

A study was carried out to ascertain whether specialists and the public at large understand the meaning and importance of mandatory health screening.

The study was conducted using questionnaires (418 respondents).Surveys of employees have been conducted both by visiting companies from different sectors and by electronically publishing a survey and allowing free access. The administration of the survey was previously agreed upon with employers or their representatives. In total, 418 questionnaires were completed in the study, of which 192 were completed electronically. Employees of various companies across Latvia participated in the survey: 101 respondents from Latgale (24\%), 74 respondents from Kurzeme (18\%), 93 respondents from Zemgale (22\%), 77 respondents from Vidzeme (18\%), and 73 respondents from Riga and district (18\%), employed in different sectors. Respondents sector-by-sector: agriculture, forestry and fisheries $34(8 \%)$; manufacturing $39(9.33 \%)$; construction $27(7 \%)$; wholesale and retail, car and motorcycle repair 76 (18\%); transportation and storage 57 (14\%); accommodation and food services 10 (2\%); public administration and defence, mandatory social security 46 (11\%); education $60(14 \%)$; health and social services $69(17 \%)$. The specific nature of each sector determines the diversity of professions (trades, jobs, and specialties) employed in enterprises. Survey participants were $147(36 \%)$ men and $271(64 \%)$ women. The largest number of respondents $(225)$ is in the age group 31-50, while in the 50 years and over there are 110 respondents and 83 respondents in the relatively smaller age group of 21-30. Respondents by years of employment: 260 (62\%) have worked for up to 15 years, 82 respondents $(20 \%)$ from 16 to 25 years, and $76(18 \%)$ more than 26 years. Respondents with higher education are the largest count - $242(58 \%), 73$ (17\%) with secondary education, and $103(25 \%)$ with vocational training. Expert interviews have been selected with the aim of clarifying why statistical data indicate the high number of occupational diseases and how to address the problem of reducing the count. 
In advance, 7 key issues were drawn up, and a date and time agreed with each expert. Both direct interviews and telephone interviews were conducted. The evaluation has been carried out by experts with experience in the field of occupational and environmental medicine. Table 1 summarizes the qualifications of the experts.

Table 1

\section{List of experts}

\begin{tabular}{|c|c|c|c|}
\hline Experts & Position, scope & $\begin{array}{c}\text { Length of } \\
\text { service, years }\end{array}$ & Education \\
\hline A & $\begin{array}{c}\text { Professor, Occupational and } \\
\text { Environmental Medicine }\end{array}$ & 45 & Higher \\
\hline B & $\begin{array}{c}\text { Doctor of Medical Sciences in } \\
\text { Occupational Medicine,lead researcher } \\
\text { at the Institute for Safety and } \\
\text { Environmental Health,Rīga Stradiňs } \\
\text { University, and labour safety specialist } \\
\text { with higher professional education }\end{array}$ & 20 & Higher \\
\hline C & $\begin{array}{c}\text { Occupational health and occupational } \\
\text { disease physician, family physician }\end{array}$ & 30 & Higher \\
\hline D & $\begin{array}{c}\text { Occupational safety and environmental } \\
\text { health }\end{array}$ & 20 & Higher \\
\hline E & $\begin{array}{c}\text { Occupational health and occupational } \\
\text { disease physician, family physician }\end{array}$ & 20 & Higher \\
\hline
\end{tabular}

The IBM SPSS 23 (Statistical Package for the Social Sciences) was used for analysis of the data generated by the employee survey.

\section{Results and discussion}

This part of article should include textual, numerical and graphical representation of results of current research along with explanation and interpretation. Comparison to results of other authors' work and discussion is much recommended.

To ascertain whether employees are provided with MHS and to assess their attitudes towards MHS, the relationship between two qualitative variables was examined and evaluated using the method of Chi $\left(\chi^{2}\right)$ square analysis in the SPSS program. In calculating the square of Chi $\left(\chi^{2}\right)$, no group should have fewer than five observations and the groups should be the same in both distributions, therefore the resulting survey data were regrouped and aggregated. Following the merger, nine sectors were reduced to three:

- Trade and services (wholesale and retail trade; repair of motor vehicles and motorcycles; accommodation and catering services; transport and storage) 143 respondents (34\%);

- Public sector (health and social services; education; public administration and defence; compulsory social security) 100 respondents ( $24 \%$ );

- Manufacturing and construction (manufacturing; agriculture; forestry and fisheries; construction) 175 respondents (42\%).

The following professions are also re-grouped:

- Manager (manager; senior specialist) 80 respondents (19\%);

- Specialist (specialist; qualified agricultural; forestry and fisheries worker) 112 respondents $(27 \%)$

- Worker (clerk; equipment and machine operator and parts fitter; sales and service; skilled worker and craftsman, elementary occupations) 226 respondents (54\%).

All obtained results or attribute relationship values p are compiled in Table 2. 
Characteristic relationship values, $p$

\begin{tabular}{|c|c|c|c|c|c|c|c|}
\hline Survey Questions F & 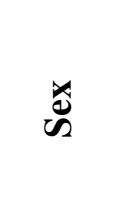 & $\underset{4}{4}$ & 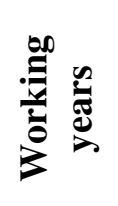 & 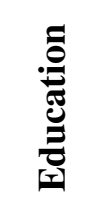 & 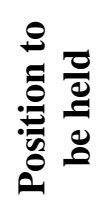 & 苛 & 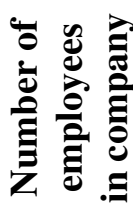 \\
\hline $\begin{array}{l}\text { (F1) Did you perform the } \\
\text { mandatory health screening when } \\
\text { you started the employment } \\
\text { relationship? }\end{array}$ & 0.172 & 0.386 & 0.059 & 0.005 & 0.380 & 0.304 & 0.004 \\
\hline $\begin{array}{l}\text { (F2) How often do you perform } \\
\text { mandatory health screening? }\end{array}$ & 0.001 & 0.001 & 0.796 & 0.001 & 0.001 & 0.001 & 0.001 \\
\hline $\begin{array}{l}\text { (F3) Has the company provided } \\
\text { you with all the necessary internal/ } \\
\text { external training on the importance } \\
\text { of the mandatory health screening? }\end{array}$ & 0.047 & 0.226 & 0.620 & 0.001 & 0.072 & 0.001 & 0.001 \\
\hline $\begin{array}{l}\text { (F4) How are you organising } \\
\text { mandatory health screenings? }\end{array}$ & 0.001 & 0.001 & 0.313 & 0.001 & 0.036 & 0.001 & 0.001 \\
\hline $\begin{array}{l}\text { (F5) Is you management interested } \\
\text { in improving the working } \\
\text { environment and reducing risks } \\
\text { that may affect your health status? }\end{array}$ & 0.086 & 0.066 & 0.325 & 0.001 & 0.018 & 0.001 & 0.001 \\
\hline $\begin{array}{l}\text { (F6) What is your attitude towards } \\
\text { carrying out mandatory health } \\
\text { screening? }\end{array}$ & 0.809 & 0.378 & 0.358 & 0.035 & 0.309 & 0.078 & 0.020 \\
\hline
\end{tabular}

The number of years worked by employees compared to the respondents' answers to all the questions asked show that there is no significant correlation $(p>0.05)$, which means that the results obtained are not relevant for the whole population; they are applicable only to the research sample. A statistically relevant relationship exists between the answers given by respondents to this question and two features: the education of employees $(p=0.005<0.05)$ and the size of the company by number of employees $(p=0.004<0.05)$. At the start of employment, those with secondary education and secondary vocational education, who work in microenterprises (1-10 employees) and medium-sized enterprises (50-249 employees), are more likely to initiate MHS. This may be explained by the specific nature of the work, as the occupational health and safety physician's confirmation is required on the adequacy of the employee's health for the work to be performed. These workers are more likely to work in companies, where the health of the worker is more often affected by the harmful effects of the working environment. On the other hand, the results show that MHS often is not initiated by employees before starting a business relationship in small businesses (10-49 employees) or large companies (250 and more employees). Employees with higher education - specialists, clerks, etc. are more often exposed to psycho-emotional risk factors: responsibility, pace of work, high demands, heavy workload, which have significant impact on the health of employees, but the results indicate that it is exactly this group that does not take part in MHS. This points to the denial of the problem, since both employers and employees are unaware of and underestimate the risk factors impacting health in the workplace. Survey data show that more often employees with secondary vocational education fail to attend MHS, mainly workers who frequently are not sent to MHS due to lack of awareness. There is a possibility that training is either nominal or does not take place at all. A significant statistical relationship exists between respondents' answers to a question and the company's providing the necessary training on the relevance of MHS and the industry sector $(p=0.001<0.05)$. The resulting data indicate that employees in the trade and services sector are partially trained. Moreover, this sector, compared to other sectors, has the highest number of employees who are not trained at all, especially in microenterprises. It indicates that these employees are more frequently exposed to the effects of harmful elements in their work environment, which leads 
to health problems, because they attend an occupational health physician without being sent by their employer, and bear the costs themselves, which is contrary to regulatory provisions [6]. A statistically significant relationship exists between respondents' answers to the question of attitudes towards MFS and the level of education of the respondents $(p=0.035<0.05)$. Employees with secondary vocational education believe that the MHS event is a formal exercise.

Results and analysis of expert interviews

A semi-structured format was used in the expert interviews. At first, all the experts answered the given questions, but then a dialogue followed, in which experts were free to express their views. Expert opinions on the topic: Does regular and high-quality MHS provide effective treatment and rehabilitation, and what attitude do employees have, and how can the academic attitude to MHS be reduced?

Expert A. Unfortunately, in our country the MHS quality and effectiveness are questionable. There is still high unemployment in the country, and employees are prepared to work until the last moment without considering their health. Often employees have to decide whether to stay employed or not, so the majority of employees remain silent about their health problems. Occupational health physicians are also various; there are cases where occupational health physicians want to earn more and this often affects the quality of the MHS, since they are mostly family doctors with a certificate in occupational health and safety, who are eligible to perform the MHS evaluation. Physicians work at many and various jobs. What sort of quality is it, if your doctor receives views and evaluates hundreds of employees a day? Moreover, there is a shortage of occupational health and safety physicians. The number of doctors currently stands at 363 and the number becomes lower each year, as young professionals leave the country, some retire. Of those who remain, more than half are in pre-retirement age - we will be without specialists in the future. It is possible to improve the situation by constantly teaching, training and testing. If this is done every day, the employees would start listening.

Expert $B$. If it is noted that during the MHS the employee provided true information on his or her state of health, and if the employer is knowledgeable about safety and protection at work and has correctly identified all the risks in the work environment that affect employee health, then the MHS will be effective. It is possible that the results were evaluated qualitatively by the occupational health and safety physician. Unfortunately, the education of employers in the field of occupational health and safety is inadequate, so many of the issues related to it are not really understood, including the objectives of the MHS. Often the MHS cards do not indicate all the harmful risks in the working environment affecting the health of employees. Employers are unaware of the importance of occupational health and safety in work environment issues. Mostly employees have a negative attitude towards the MHS, they do not want to participate, because a physician's conclusions can leave them without work. Efficiency and quality could be improved through cooperation between occupational health and safety physicians, employers and employees. Both employers and employees should be informed and trained.

Expert $C$. Frequently during the MHS, occupational and work-related diseases, as well as other types of health issues, such as cancer, tuberculosis, high blood pressure, etc. are detected. In practice, this is very common. If the disease or signs of disease are detected during the early stage, the employee has the possibility of starting treatment and rehabilitation more quickly, which allows the employee to return successfully to work. Employees are afraid of losing their jobs, so they often do not want to admit or solve their problems, but they will nevertheless try to persuade a doctor to sign an opinion on the suitability of their health for work. Participation in the MHS event consists of 3 members - employee, employer and occupational health physician. Each has its own duties and responsibilities. Not everyone relates to it in good faith or conscientiously. A casual attitude has been found even among colleagues. For example, the results of the analyzes that are needed in the future to assess the health status of the employee in accordance with the work to be performed are not fully described. In addition, employees who do not openly reveal their existing health problems, may in future suffer an unavoidable and incurable health disorder. As long as there is no mutual cooperation or clarity and awareness of the MHS objectives, there will be no efficiency. Employers, including labour safety specialists, do not understand the advice and instructions of occupational health and safety physicians. Often in practice the occupational health and safety physicians use short phrases of a professional nature, which they believe should be understood and enforced by employers or labour 
safety professionals. Unfortunately, that is not the case. Not all companies have labour safety specialists, whose responsibilities include the prognosis, identification, prevention and control of harmful work conditions. Labour safety specialists lack medical knowledge. Therefore, to change the situation, it is necessary to begin by understanding what we are talking about and what we want.

Expert $D$. The quality and effectiveness of the MHS depend first and foremost on the competence of the occupational health physician: how the physician will assess the state of health of the employee, how much time will be allocated to the employee in order to obtain as much information as possible. Occupational health physicians often assess the health status of hundreds of employees during a working day, depending on the work to be done, so in our country the quality is highly questionable and needs to be improved. The employees deliberately go to a physician from whom it is easier to get an opinion. Improving outcome measures would improve and reorganize the e-health system. By that I mean, providing occupational health physicians with access to the health histories of employees to observe the dynamics of health. This will, firstly, accelerate the duration of the MHS, as otherwise it is often necessary to send employees to different specialists. Secondly, this will enable physicians to follow the real situation sequentially.

Expert E. The MHS will be effective and qualitative, if the participating parties fulfil their obligations conscientiously and in good faith. Employees do not understand the importance of the MHS measure and frequently confuse the MHS with other health tests, developing resistance to the MHS. Unfortunately, not every company has a labour safety specialist, who is obliged to anticipate, identify and eliminate harmful risks in the working environment. Employers are trying to avoid liability as much as possible. For example, it is very common to enter into a fixed term contract with a company for a specified service. There is a need to improve the level of knowledge on occupational safety in work environments and the significance of the MHS for both employers and employees.

\section{Conclusions}

1. The interviews in the study showed that labour protection specialists do not understand the recommendations/instructions of the occupational health physician on the MHS cards, because they are not familiar with medical professional language.

2. As a result of this research, it has been found that it is necessary to increase the competence of labour safety specialists by improving the master program, which would raise the level of information taught and attract guest lecturers with commensurate expertise in occupational medicine.

3. The study pointed to the need to organize appropriate training for employers, workers, and labour protection specialists on the importance of the MHS.

\section{References}

[1] Profesionālās izglītības likums (Vocational Education Low). (In Latvian). [online] [04.01.2020.] Available at: https://likumi.lv/doc.php?id = 20244

[2] Darba aizsardzības vecākā speciālista profesijas standarts (The Professional Standard of Senior specialist in labour protection). 2011.(In Latvian).[online] [04.01.2020.] Available at:https://visc.gov.lv/profizglitiba/dokumenti/standarti/ps0100.pdf

[3] Darba aizsardzības vecākā speciālista profesijas standarts (The Professional Standard of Senior specialist in labour protection). 2011.(In Latvian).[online] [04.01.2020.] Available at:https://visc.gov.lv/profizglitiba/dokumenti/standarti/ps0100.pdf

[4] Eglīte M. Darba medicīna. - 2.pārstrād. un papild. izd. - Rīga: Rīgas Stradiṇa universitāte (Work medicine. - 2 ed. Riga, Riga Stradins University). 2012. p. 665. (In Latvian)

[5] Hackl F., Halla M., Hummer M., Pruckner G. J. The Effectiveness of Health Screening. IZA Discussion Paper No. 6310. [online] [04.01.2020.] Available at: http://ftp.iza.org/dp6310.pdf

[6] Ministru kabineta Nr.219 "Kārtība, kādā veicama obligātā veselības pārbaude" (Cabinet Regulation No. 219 Procedures for the Performance of Mandatory Health Examinations).(In Latvian).[online] [05.01.2020]. Available at: https://likumi.lv/ta/id/189070-kartiba-kada-veicamaobligata-veselibas-parbaude

[7] Černova E., Vanadziņš I. Arodslimību diagnostikas problēmas Latvijā. RSU zinātniskā konference Darba un vides veselība, arodslimības, farmācija (Problems of diagnosis of 
occupational diseases in Latvia. RSU Scientific Conference Occupational and Environmental Health, Occupational Diseases, Pharmacy), 2017, 31p.

[8] Eglite M.,Vanadzins I., Martinsone L., Bake M. A., Sprudza D., Martinsone Z., Martinsone I., Kalve I., Reste J., Cirule J., Seile A.Assessment of Occupational Health and Safety System in Latvia. International Journal of Safety and Security Engineering, vol. 2, Issue 4. 2012, pp.305 316.

[9] Brizga D., Peks L. Workplace wellness and specialists' attitude to work safety. In V. Dislere (Ed.), The Proceedings of the International Scientific ConferenceRural Environment. Education. Personality (REEP), 7, Jelgava: LLU, 2014, pp. 90-96. Available at: https://llufb.llu.lv/conference/REEP/2014/Latvia-Univ-Agricult-REEP-2014proceedings-9096.pdf

[10] Brizga D. Darba un civilās aizsardzības kompetences veidošanās un attīstība studiju un darba vidē (Formation and Development of Labour and Civil Protection Competence in the Study and Work Environment). Promocijas darba kopsavilkums (Summary of the Doctoral thesis). [online] [05.01.2020]. Available at: https://llufb.llu.lv/dissertationsummary/education/Dace_Brizga_prom_darba_kopsavilkums2019_LLU.pdf

[11] Glanz K., Rimers B. K., Viswanath K. Health Behavior and Health Education: Theory, Research, and Practice (4th ed.). San Francisco, CA: Jossey-Bas, 2008.

[12] Lowe G. S. Healthy Workplaces and Productivity: A Discussion Paper. Ottawa: Public Works and Government Services Canada, 2003. 